\title{
The Impact of the Financial Crisis on Business Ethics in the Banking Sector: A Case Study from Slovakia ${ }^{1}$
}

\section{Jaroslav Belás ${ }^{2}$}

\begin{abstract}
The importance of ethical standards for financial markets is based on the purpose of commercial banks and other financial institutions which operate with money of others. Besides significant economic implications, the financial crisis has also revealed considerable lack of moral values in commercial banking, which has been reflected by a very unscrupulous approach of bankers to their clients. The crisis has also caused a fundamental turnaround in public opinions on commercial banking and increased the pressure on application of moral principles in banking, which represents an appropriate complement of banking regulations.

The aim of this article is to determine the basic attributes of business ethics in commercial banking and quantify changes in moral attitudes of bank employees in Slovakia through own research, which occurred during the financial crisis. Moral attitudes of bank employees are analyzed in relation to reaching customer satisfaction.

The research focuses on identificating satisfaction of bank employees and also on how their satisfaction reflects acceptance of customers' needs. A part of the research also deals with evaluation of customer satisfaction in the same timeframe.

The results of our empirical research show that the low level of satisfaction and loyalty of bank employees is transferred to the low acceptance rate of customer need to sell bank's products in the banking sector in Slovakia. The low level of satisfaction and loyalty has also caused a decline in the overall customer satisfaction. Index of personal satisfaction of bank's customers has slightly increased in the examined period, but its current level is still very low.
\end{abstract}

Key words: corporate social responsibility in banking sector; morally attitudes of bank employees, satisfaction of bank's customers

JEL Classification: G21, Z13, M14, M12

\section{Introduction}

Economic activities of individuals and companies occur in social system. According Hofreiter, the economic sociology emphasizes that economic life is constantly placed in a social and cultural context. The concept of placing economic action in a social and cultural context appears to be a suitable alternative towards economic individualism and rationality $(2011$, p. 530).

\footnotetext{
${ }^{1}$ This paper was supported by Project No. IGA/FaME/2013/010: Satisfaction mirror effect and bank financial performance.

${ }^{2}$ Department of Enterprise Economics, Faculty of Management and Economics, Tomas Bata University in Zlín, Mostní 5139, 76001 Zlín, belas111@gmail.com
} 
Technocratic perception of the market is prevailing in economic theories. According to Lisý et al., the market allows the most efficient allocation of production and utilization of scarce resources in an economic context, but the profit motive of the market mechanism leads to devastation of nature and dire social consequences. The market mechanism is "socially blind," and market imperfections require additional government interventions in the economy (Lisý et al., 2007).

The financial market provides the key economic function of transferring money from those who have saved surplus money (they spend less money than they earn) to those who do not have enough money (because of their willingness to spend amounts of money which exceed their income (ECB, 2001).

In the process of production, distribution and realization of gross domestic product (GDP), the complex monetary transactions are performed in the economy through which the money supply of individual economic subjects is changed as well as by consuming components of GDP, occurs to satisfy the needs of individual subjects. Based on principles of a market mechanism, the role of money in the process is to assign adequate tangible and intangible portions of GDP to each economic subject, and such distribution is based on its personal participation in the process (Belás, 2010).

Hofreiter argues that modern society results in creation of new situations of uncertainty through the impact of new technologies and products caused by changing commodity flow and cash flow in the economic sphere. This process may not lead to formation of the most efficient, the fairest and the most economically profitable process, but leads to formation of social tools mitigating uncertainty which is determined by social structure, distribution of the society power, culture and ideology. (2011, p.537) These attributes are reflected in the financial system by information asymmetry which leads to adverse selection and moral hazard (Polouček, 2006).

As the failure of commercial banks reflected itself in the real economy, and the quality of life of hundreds of millions people around the world decreased due to higher unemployment as a result of reduced global consumption, the financial crisis made the public focus its attention on the financial industry (San-Jose, Retolaza and GutierrezGoria Goire, 2011; Tea, Paulišič and Krstinič-Nižič, 2011). In this process, the moral failure of participants in the financial system (Graafland and Van de Ven, 2011; Fassin and Gosselin, 2011), and mostly the total lack of decency in relation to customers and society (Chatterjee and Lefcovitch, 2009) were the most important factors.

Rather paradoxically, the current economic crisis was created in a sector which is highly regulated. With the impact of the global crisis, regulatory authorities gradually tightened banking regulations (Basel Committee on Banking Supervision, 2010, 2009). Conditions in the credit risk of the banking sector due the adverse economic development are also aggravated. These factors create enormous pressure on the performance of the banking sector and can cause a decrease in financing of firms and households, and in result may have a negative effect on the economic growth (BlundellWignall and Atkinson 2010, Härle, Heuser, Pfetsch and Poppensieker, 2010).

The aim of this article is to determine the basic attributes of business ethics in commercial banking and quantify changes in moral attitudes of bank employees in 
Slovakia through own research, which occurred during the financial crisis. Moral attitudes of bank employees are analyzed in relation to reaching customer satisfaction.

The research focuses on identificating satisfaction of bank employees and also on how their satisfaction reflects acceptance of customers' needs. A part of the research also deals with evaluation of customer satisfaction in the same timeframe.

\section{Social Context of Commercial Banking}

Commercial banks are financial intermediaries that play a significant role in national and international economies (Icke, Caliskan, Ayturk and Icke, 2011, p. 289), and their powers affect the social system (Van Nimwegen and Van Luijk, 2004, p. 101).

Rose (2012) defines banks as the most important financial economic institutions which accept deposits, provide loans and offer the widest range of services of all financial institutions. Bank is perceived as the important economic entity without any participation in the shaping of the social system.

Banking system is determined by factors that significantly affect the business area of commercial banks such as credibility of the banking sector, money as a line of business and atypical balance sheet of commercial banks. These factors are the main reason for the strict regulation of the banking sector (Belás, 2010).

Commercial banks operate with money of their depositors and other creditors which it receives on the financial market. This money is usually guaranteed by the state and that results in the fact that the bank operates with "a special type of public resources". In this context, the credibility of the banking sector is particularly important.

The structure of balance sheet of assets and liabilities is an important particularity of the commercial bank's activities because it is clearly dominated by foreign sources which are preferentially accumulated by households in the form of small deposits. Therefore, a commercial bank operates with money of its depositors on its own account and to its own risk while trying to maximize leverage effect. In the banking sector, leverage (the ratio of total assets and equity) affects with extraordinary intensity because the ratio of equity to total assets is around 5\% in the standard commercial bank. Therefore, an atypical balance of commercial bank is a great challenge for its management and the political system as a collapse of large banks, or any commercial bank can cause massive social turbulences. The balance of commercial banks is atypical and significantly asymmetric in comparison to others. It is inherent in the system and also represents the most significant risk in banking sector. It is obvious that any bank cannot be and is not completely protected from financial shocks. This issue cannot be solved optimally with the fact that systematic risk is constantly presented in the banking system. This can be substantiated by the fact that intense turbulences are still generated in strictly regulated banking business industry and affect the economic and social system (Belás, 2010).

Mejstřík, Pečená and Teplý (2008, p. 200) present a specific property of banks in their safety net, which includes government guarantees of banking business in the form of deposit insurance, the function of the central bank as a lender of last resort and doctrine of "too big to fail."

If we accept the submitted argument about specific position of banks in the socioeconomic system, it is necessary to examine the issue of commercial banking in the 
broader economic and social context, and of course require a higher level of social responsibility of banks for their business and a higher level of moral principles application in the banking business.

\subsection{Business ethics in the commercial banking}

Managers and their firms are not isolated from a society. According to Rendtorff and Mattson (2011, p. 39-40), companies are seen as human communities using social practices to achieve common social objectives. These objectives are implemented through a relationship of trust and authentic relationships with customers. The most important ethical principles supporting "well-being of customers" are as follows: client autonomy; dignity; honesty; vulnerability of the client; and representation of basic prerequisites for good access to customers.

According Heskett (1994), the profit and company growth are primarily stimulated by customers loyalty, which is immediately formed by customer satisfaction. Customer satisfaction is determined by quality of services which is created by satisfied, loyal and productive employees (service-profit chain effect). The service-profit chain effect has been analyzed by many other authors in their works (Yee, Yeung and Cheng 2010; Gelade and Young 2005; Kamakura et al., 2012, Saura et al., 2005). Walker, Smither and Waldman (2008) argue that a high rate of customer satisfaction is extremely important in retail banking because it represents the only form of differentiation from competitors. Through a positive change in leadership and corporate culture, positive changes in satisfaction and thus profitability of individual customers can be expected. According Graafland and Van de Ven (2011, p. 616), emphasis on the social responsibility of banks requires increased professionalism of those who works in financial sector, stronger focus on ethical codes, personnel skills verification and other approaches such as transparency, focus on interests stakeholders, cooperation with social institutions.

Robin (2008) states that a company would like to operate in an efficient economic system which creates opportunities for economic prosperity growth and happy people's life. The mission of ethics is to minimize the abuse of company's power in the mutual exchange relations and reduce negative impacts on people's daily lives. The fundamental question regarding business ethics is how to make capitalism more ethical. An important part of this analysis is to understand the nature of trade relations with stakeholders. A sense of their own profit from these relationships prevails for all business participants, which the author defines as a win-win situation (customers buy products because they believe that it will bring them more value than paid before; employees work for companies because they expect higher value than pay; society demands a relationship with companies in a similar way). On the other hand, there are firms within these relationships which expect a profit from these relationships with stakeholders which would exceed their price. Although the exchange relationship constitutes a free choice for each participant, there are large differences between the power of companies and stakeholders (gaps in knowledge, information etc.). And for these reasons, the application of business ethics in combination with the legislation of the State is required. According to the author, two basic dimensions of relationships with stakeholders are honesty and respect. 
The aim of ethical banking is to achieve economic benefits to include social goals, too, while two objectives groups are relevant in the socio-economic system (San-Jose, Retolaza and Gutierrez-Goiria, 2011, p. 152; Icke, Caliskan, Ayturk and Icke, 2011).

Fassin and Gosselin (2011, p. 187) argue that large institutions had strong ethical culture such as Fortis, Arthur Andersen \& Co, AIG and fail anyway. These cases show the discrepancy between official statements and proceedings of top management. Failure of management and ethics can lead to strategic mistakes with fatal consequences for the company. These cases and the global financial crisis highlight the need for strong ethics and responsibility in the company's management. According Palomino and Martinez (2011), efficiency of ethics programs is different in the bank. Some programs are primarily focused on achieving a favorable image in relation to the socioeconomic institutions (government, media, society, customers), and do not have a significant impact on employee ethics.

According to Gibbons (2011), many banks do not act transparently in Great Britain, the scope of the information provided is not sufficient in comparison with other European countries; quality information is absented for people who are in financial difficulties etc. Tea, Paulišič and Krstinič-Nižič (2011) evaluated ethical aspects of banking in Croatia, finding out that the banking culture lacks honesty, awareness, responsibility, creativity, objectivity and professionalism. The moral code does not include rights and obligations for employers and employees, ethical principles in marketing and advertising, ethical aspects of price setting, corporate responsibility towards society and the environment.

Watkins (2011, p. 366) argues that banking is a typical capitalist activity aimed to gain profit. Policy of laissez-faire believes that individuals and companies may seek to increase their financial fortune without any limitations. Financial market presents unlimited opportunities for fortune growth. These factors operate more intensively if profitable opportunities grow in the economy. For example, Goldman Sachs is also involved in ethically problematic activities that generate high profit enormously. According to Chatterjee and Lefcovitch (2009), banks are predominantly oriented to maximizing profits, and behave totally ruthlessly in their operations against depositors, investors and general public interests. In their attempt to maximize their own profit, banks violate laws, regulatory rules and ethical codes. According to Fassin and Gosselin (2011, p. 187), the more bankers talked about social responsibility, the more they focused on increasing shareholders value, their own personal bonuses and on the level of their "golden parachutes" after the financial crisis had broken out.

Chatterjee and Lefcovitch (2009) claim that the importance of ethical standards for financial market consists in the fact that financial markets operate with money of other owners and risk may generate profit as well as losses. A risk which is too high must be minimized for two reasons: it must be maintained the confidence in investment and the undertaken risk may not mean a dangerous investment. Downfalls of banks are usually caused by bad-risk investments. In this process, expectations of extremely high profit have a dazzling effect on bank managers and selfish interests of banks dominate in their proceedings. Public interests are relegated to the sidelines.

Rendtorff and Mattson (2011, p. 39) indicate that the banking ethics is all about good customer relations. Customer satisfaction is determined by employees' satisfaction, i.e. 
by the satisfaction mirror effect (Maddern, Maull and Smart, 2007; Babakus, Yavas, Karatepe and Avci, 2003).

\subsection{The Importance of Customer Satisfaction for Commercial Banks}

By achieving their objective, banks do not pay sufficient attention to the correct approach to their clients in real life. This argument is confirmed by Greg Smith, a manager of the largest investment banks in the world, Goldman Sachs, who said upon leaving the bank in March 2012 "that he always took care to advise their clients what he considered for them to be correct, even if it meant less money for the company. That view of the matter, however, is increasingly unpopular in Goldman Sachs" (Nemec, 2012).

Clients required a high level of acceptance of their needs and accurately provided services from bank employees (Lages, Pierce, 2012). According to Croxford, Abramson and Jablonowski (2006), customer services, brand, quality and price of bank's products and services are the dominant aspects of consumer behavior. Berry (2005) states that banks do not understand needs of their clients, and not take advantage of many opportunities to establish stronger relationship with their clients.

Chakrabarty (2006) defined four basic factors that affect the overall customer satisfaction. These factors have been arranged according to their importance: client satisfaction with a branch (i.e. the speed of service, access of each employee, privacy, and opening hours); economic satisfaction (fees, interest); satisfaction with the remote access (i.e. the level of e-banking), and availability of ATMs.

Baumann, Elliott and Burton (2012) examined loyalty of bank customers, which was based on the overall satisfaction, emotional attitudes towards bank, service quality, perception of market situation (costs and benefits of the change) and customer characteristics. According to the authors, combination of two factors, namely the emotional connection with the bank and economic benefits appears to be unbreakable shield for relationships with bank customers, and should protect the bank from its competitors.

Many studies confirm that banks do not understand financial needs of their clients. A survey by Ernst \& Young (2012) was conducted in 35 countries all over the world on a sample of 28,560 respondents. This survey shows that according to opinions of clients, banks do not recognize their real needs and also do not adjust their products to their needs. The reason for this is that only $44 \%$ of respondents worldwide $(27 \%$ of respondents from the Czech Republic) believe that their bank can adapt its products to their needs. According to $34 \%$ of Czech respondents, a simplification of the fee structure would lead to increased satisfaction with banking services. The amount of bank fees is regarded as the most important impulse to change the bank as $69 \%$ of Czech customers would change their banks because of this factor (compared with European average of $53 \%$ of respondents). A bad experience in a bank office is the second most important reason to change the bank.

A survey by Deloitte (2012) has indicated strong dissatisfaction of Slovak consumers with the amount of bank fee and inadequate services. Differences between Slovak customers and customers from the Czech Republic or Poland are especially in their loyalty to their banks, which is significantly lower. While $17 \%$ of Czech respondents 
and $12 \%$ of Polish respondents have changed their banks, it was actually up to $52 \%$ of respondents in Slovakia.

Satisfied customers are very important for current and future performance of commercial banks. Korauš (2011) states that satisfied customers stay loyal to their banks, and it requires five times less effort, time and money to keep old customer than to get a new one. A loyal customer is willing to pay a higher price. To attract a satisfied customer to a competitor means to reduce the amount of a product price by $30 \%$. A satisfied client represents free form of advertising, is willing to purchase new products offered by the bank, and causes retrospectively a sense of satisfaction and pride in employees' work and business.

\subsection{Basic Attributes of Employee Satisfaction in the Banking Sector}

Employee satisfaction is formed by several factors and significantly determines the loyalty of employees, which means the fact that higher quality of services creates a higher customer satisfaction.

Saari and Judge (2004) suggest that satisfaction with the nature of performed job (the job challenge, the autonomy, the diversity and the job area) represents the most important factor of the formation of satisfaction with job among employees. According to the authors, employee satisfaction is closely related to customer satisfaction through a high quality of services. Bhutto, Laghari and Butt (2012) examined the impact of organization' climate on the employee satisfaction and defined the following three factors which have a positive and significant impact on the job satisfaction: organizational structure, identity, and interpersonal relationship. Babakus, Yavas, Karatepe and Avci (2003) analyzed the essential attributes of the growth of the financial performance of the commercial bank, and stated that the area of job satisfaction is an important factor that significantly affects ability of staff to provide quality data to their clients. Similar conclusions are indicated also by Matzler and Renzl (2006), Melton and Hartline (2010), or Saura, Contrí, Taulet and Velasquez (2005). Yee, Yeung and Cheng (2010) indicate that loyal employees have many opportunities to understand and meet specific needs of bank customers, which represents a higher quality of services. According to the authors, the loyalty of employees represents an essential factor in the growth of quality service, the customer satisfaction, and loyalty and plays a major role in the process of increasing of the financial performance. Lages and Piercy (2012) argue that customers require a high level of acceptance of their needs and accurate custom services. In this context, the correct understanding of customer needs as a result of employee job satisfactionis the key element to improve the quality of provided services. Coelho and Augusto (2010) investigated the basic characteristics of job application for the creativity of staff working in customer services, and provided a conclusion that creating a favorable working environment stimulates efficiency of bank employees in carrying out their jobs. According to authors, managers who are working in the service sector should consider the autonomy of employees, their diversity of the job, the quality of the feedback and their identity in the job process; because these presented attributes create a creative approach to meeting job requirements. Maddern, Maull and Smart (2007) examined the relationship of customer satisfaction depending on the employee satisfaction and quality services in the area of the financial services in the United 
Kingdom. Results of this study confirm a high correlation between employee satisfaction and customer satisfaction.

Therefore, it is important to examine the employee satisfaction and the acceptance of customer needs, because these factors can create suitable conditions for successful operation of the bank on the market in a competitive environment. Personal productivity is significantly formed by relationship to employer and customers, which determines the level of work quality in all areas of the bank, and potentially increases its productiveness. These attitudes also shape the social system in which banking business actors operate.

Banks in Slovakia (as well as in other countries) have their own ethical code, in which they undertake to offer only services that meet customer requirements and interests and will not offer services which clearly do not meet their needs (Slovenská banková asociácia, 2007). What is the reality? This question will be examined by our research, too.

\section{Methodology}

Attitudes of employees of commercial banks in Slovakia were examined by the means of a questionnaire and structured interviews. Questionnaire survey was first carried out in 2008 (before the crisis) on a sample of 49 respondents. There were bank employees who sell banking products to clients in the branch. The results of the research were verified through structured interviews with 10 bank managers who worked in the middle or top management in Slovakia. In 2012, the questionnaire survey was repeated on a sample of 116 salesclerks. Its results were subsequently compared to opinions of the 13 managers.

Such information is usually confidential and therefore, banks are unwilling to provide information through official channels which are the subject of this research. Therefore, questionnaires have been completed during training events for employees in the banking sector, and this is the reason for the limited number of respondents. The research sample was selected by a random selection. Questionnaires were anonymous and respondents could answer truthfully without any sanctions or penalties. The questionnaire was conducted on the sample of employees from 13 Slovakian banks in 2008 and on the sample of employees from 9 Slovakian commercial banks in 2012. Structured interviews were conducted on the basis of author's personal relationships with the selected bank managers.

Customer satisfaction in Slovakia was examined by the means of a questionnaire survey. The questionnaire survey was first conducted in 2008 on a sample of 298 respondents, who were clients of commercial banks. In 2012, the questionnaire survey was repeated on a sample of 320 bank customers. The research sample was selected by a random selection. Questionnaires were distributed through agents - students of the University of Economics in Bratislava, and through students of the Pan-European University in Bratislava.

The questionnaire was developed in 2008 and it was based on the results of foreign studies (Berry, 2005; Croxford, Abramson and Jablonowski, 2006; Chakrabarty, 2006) and author's own knowledge of this issue. The same questionnaire was used in 2012 
because this method offered the possibility to compare the results in the conclusion of this overall research.

Within empirical research, five scientific assumptions were set. The scientific assumptions and different quantitative criteria were determined by expert judgment.

P1. Employee satisfaction decreased during the crisis as a result of bigger requirements on the productiveness. The level of employee loyalty, which has been tested at a significant level of 0.05 , decreased. The index of salesclerks' satisfaction decreased at least by $10 \%$.

P2. Attitudes of bank personnel changed to the detriment of customers during the crisis, which means that the level of decency decreased as salesclerks transformed the increased pressure on their productiveness by the bank management to the form of unfair sales. The number of salesclerks who focused on selling at top prices and who accepted the purchase of improper product by bank customer increased. The index of acceptance of customer needs decreased at least by $10 \%$.

P3. The overall satisfaction of bank customers decreased in Slovakia. The index of customer satisfaction declined at least by $10 \%$.

P4. Availability of banking products and services through electronic banking was the most important reason of customer satisfaction. Electronic banking increased number of clients who consider availability of products and services to be the most important source of their satisfaction.

P5. Feelings of bank customers about business communication between banks and their customers did not change at all. Clients thought that banks wanted to sell something to them and make money on them. Customers also felt that bank environment has a serious impression.

Preference changes of subjects and their relationship to function of time were examined via Pearson statistics for testing the conformity of the structure proportions. Due to the failure of asymptotic requirements for this test, a series of 5000 Monte Carlo replications of the original data was carried out. When any of assumption was not fulfilled and Monte Carlo method was employed, the number of degrees of freedom was not printed (as in case of meeting the assumptions) and the conclusion can be read only from the P-value.

We tested the overall change in the structure of the table through the P-values. P-value lesser than $5 \%$ leads to rejection of the null hypothesis which states that there is no relationship between the changes of the structure of the responses.

Research results from 2008 were compared to the results of the 2012 research by the means of test of equal proportions. We assumed to have independent data obtained by selection of the range $\mathrm{n} 1$ from binary categorical variable with proportion $p 1$ as a proportion of interest (i.e. positive answer to question), and sample data from 2012 of size $n 2$ and the corresponding proportion $p 2$. Null hypothesis for proportion test is stated in terms of proportion equality: $H_{0}: p_{1}=p_{2}$ which can be restated to $H_{0}: p_{1}-p_{2}=0$ form. New statistics $U$ represents random variable describing the 
difference of two sample units, counting for different sample sizes and different variation.

Random variable $U$ follows (if the criteria as sample size are met) a standard normal distribution. If test-value is higher than the critical value (quantile of the standard normal distribution $u_{1-\alpha / 2}$ ) the null hypothesis is rejected. In this case the difference between the replies on the questionnaire questions differs significantly.

Calculations were performed in $\mathrm{R}$ package (contingency tables). P-value is the main output. Significance level was set as $\alpha=0.05$.

The relationships between staff satisfaction and the level of acceptance of customer needs were evaluated through the Index of salesclerk satisfaction and Index of acceptance of customer needs. The overall customer satisfaction and satisfaction with quality of bank personnel were expressed by Index of customer satisfaction and Index of customer satisfaction with bank employees. These indexes have been calculated as the arithmetic average of the percentages of those factors which are important and were obtained in this research. Indexes are used to quantify a simple presentation of the identified trends.

Index of salesclerk satisfaction (Iss) contains the level of staff loyalty and acceptance of their need in management process. Iss=(loyalty rate + acceptance rate $) / 2$. Index of the acceptance of customer need $($ Ian $)=($ suitable product sales + offer a suitable product in the case of inappropriate customer's choice)/2. Index of customers' satisfaction (Ics) was expressed by a proportion of satisfied customers on the total number of respondents in the survey. Index of customer satisfaction with bank employees (Ice) was created through arithmetic average of partial attributes of customer satisfaction (Ice = proportion of respondents who were satisfied with fast services in the branch + proportion of respondents who appreciated comfortable and friendly services in the branch + proportion of respondents who considered that their bank is interested in solving of customers' needs + proportion of respondents who thought that employees in their bank try to help and advise them/4).

In Tab. 6 and Tab. 9, Index of change (Ich) was calculated as a difference between value of parameters in 2008 and 2012, and divided by value which was calculated in 2008.

\section{Results}

Employee satisfaction determines the level of their loyalty. Loyal employees have generally better approach to accept customer needs in the bank. Employee satisfaction in the Slovak banking sector was investigated through two questions. These questions focused on employee loyalty and acceptance of employees' opinions in the management process. Results are shown in Tab. 1 and Tab. 2. 
Table 1: Results of Loyalty Rate of Bank Employees in Slovakia

\begin{tabular}{|l|r|r|r|}
\hline $\begin{array}{l}\text { How would you express your feelings towards the } \\
\text { bank? }\end{array}$ & $\begin{array}{r}2012 \\
\text { in } \%\end{array}$ & $\begin{array}{r}2008 \\
\text { in } \%\end{array}$ & $\begin{array}{r}\text { p-value } \\
\text { (statistics) }\end{array}$ \\
\hline 1. I am proud of the bank I work for & 13 & 37 & $\begin{array}{r}<0.01 \\
(10.57000)\end{array}$ \\
\hline 2. If they pay me well, other factors do not matter & 22 & 24 & $\begin{array}{r}0.93100 \\
(0.00800)\end{array}$ \\
\hline 3. Bank is indifferent to me & 9 & 8 & 31 \\
\hline 4. I do not think about it & 56 & \multicolumn{3}{|c|}{ p-value $=<0.01$} \\
\hline
\end{tabular}

Source: Own Source

Statistical parameters $\chi^{2}$ and p- value indicate the overall change in salesclerk attitude. In 2012 compared to 2008, a statistically significant decrease of number of salesclerks, who were proud of the bank which there was working for, was observed. Number of salesclerks, who were indifferent to this kind of question, increased.

Table 2: The Acceptance of Opinions and Comments of Salesclerks by Their Managers

\begin{tabular}{|l|r|r|r|}
\hline How do you evaluate the manager's approach & $\begin{array}{r}2012 \\
\text { in \% }\end{array}$ & $\begin{array}{c}2008 \\
\text { in \% }\end{array}$ & $\begin{array}{r}\text { p-value } \\
\text { (statistics) }\end{array}$ \\
\hline $\begin{array}{l}\text { 1. They hear my opinions, ideas and } \\
\text { comments and try to accept them }\end{array}$ & 65 & 73 & $\begin{array}{r}0.35600 \\
(0.84800)\end{array}$ \\
\hline $\begin{array}{l}\text { 2. They hear my opinions, but they do not } \\
\text { accept anything }\end{array}$ & 30 & 18 & $\begin{array}{r}0.16900 \\
(1.88800)\end{array}$ \\
\hline 3. They do not even hear me & 0 & 2 & - \\
\hline 4. I do not even try it & 5 & 7 & - \\
\hline \multicolumn{1}{|c|}{$\chi^{2}=4.62250$} & \multicolumn{4}{|c|}{-value $=0.18240$} \\
\hline
\end{tabular}

Source: Own Source

In 2012, no statistically significant change in the acceptance of salesclerk opinions and comments was observed. Research shows that in 2012, $65 \%$ of bank employees reported that managers hear their ideas, observations, comments and try to accept their comments; $30 \%$ of bank's front-office employees said that their managers hear them but do not accept anything; and 5\% of bank employees are afraid to present their comments because of fear of losing their jobs. In comparison with 2008, the situation in this area deteriorated slightly.

The results of the research show that employee satisfaction declined due to the crisis. The level of loyalty of bank employees to their employer in Slovakia is low and the crisis brought a negative change of attitude.

In the next phase of our research, we examined the level of acceptance of client needs from salesclerk point of view. The moral attitude of salesclerks was verified through two questions. We wanted to identify the facts which salesclerks focused on, when they would like to sell bank's products, and what they would to do if the client chose wrong banking products. Results of the survey are shown in Tab. 3 and Tab. 4. 
Table 3: Priorities of Salesclerks

\begin{tabular}{|l|r|r|r|}
\hline When doing business you focus primarily on? & $\begin{array}{r}2012 \\
\text { in } \%\end{array}$ & $\begin{array}{r}2008 \\
\text { in } \%\end{array}$ & $\begin{array}{r}\text { p-value } \\
\text { (statistics) }\end{array}$ \\
\hline $\begin{array}{l}\text { 1. To achieve a feeling in the client that his bank } \\
\text { sells the highest quality possible }\end{array}$ & 35 & 43 & $\begin{array}{r}0.40000 \\
(0.70900)\end{array}$ \\
\hline 2. I try to sell for the highest price & 17 & 2 & $\begin{array}{r}0.01500 \\
(5.86000)\end{array}$ \\
\hline 3. I try to sell regardless of price & 4 & 7 & 46 \\
\hline 4. I only sell a product which is suitable for the client & 44 & $\begin{array}{r}0.85740 \\
(0.03200)\end{array}$ \\
\hline 5. They did not respond to this question & 0 & 2 & p-value $=0.03579$ \\
\hline \multicolumn{2}{|c|}{$\chi 2=9.57600$} & \multicolumn{3}{|c|}{} \\
\hline
\end{tabular}

Source: Own Source

Statistical parameters $\chi^{2}$ and $\mathrm{p}$ - value show the overall change in salesclerk attitude. Number of those salesclerks who tried to sell banking products at the top prices increased significantly. The largest number of salesclerks, but $44 \%$ of them said that they focused on selling an appropriate product.

Table 4: Responding of Salesclerks to a Wrong Choice Made by Clients

\begin{tabular}{|l|r|r|r|}
\hline $\begin{array}{l}\text { Question 4: If you have a feeling that the client has } \\
\text { chosen a wrong product, what would you do? }\end{array}$ & $\begin{array}{r}2012 \\
\text { in \% }\end{array}$ & $\begin{array}{r}2008 \\
\text { in \% }\end{array}$ & $\begin{array}{r}\text { p-value } \\
\text { (statistics) }\end{array}$ \\
\hline $\begin{array}{l}\text { 1. If he was free to choose, I would sell him the } \\
\text { product }\end{array}$ & 30 & 4 & $\begin{array}{r}<0,01 \\
(12.02200)\end{array}$ \\
\hline $\begin{array}{l}\text { 2. I will sell the product and gently draw his } \\
\text { attention to possible risks }\end{array}$ & 48 & 35 & $\begin{array}{r}0.11520 \\
(2.05500)\end{array}$ \\
\hline $\begin{array}{l}\text { 3. I will explain to him disadvantages of the selected } \\
\text { product and I will offer him another suitable product }\end{array}$ & 22 & 53 & $\begin{array}{r}<0.01 \\
(13.60500)\end{array}$ \\
\hline 4. I do not deal with this problem & 0 & 4 & - \\
\hline 5. I do not know & 0 & 4 & p-value $=<0.01$ \\
\hline \multicolumn{2}{|c|}{} \\
\hline
\end{tabular}

Source: Own Source

Statistical parameters $\chi_{2}$ and $p$ - value confirmed the change in attitude of salesclerks who increasingly accepted the purchase of inappropriate products by the client. While in $2008,53 \%$ of respondents informed the client about disadvantage of the product and offered him another suitable product, this approach was adopted only by $22 \%$ of respondents in 2012. In 2012, 48\% of respondents (it was 35\% in 2008) indicated that this kind of product was sold to the client and gently mention its risks. Their decision to sell wrong product to the client was increasingly justified by client's free choice in 2012 (30\% of responses compared to $4 \%$ responses in 2008). An answer that they do not deal with this issue was reported by $4 \%$ of respondents in 2008 and none of them in 2012 . Pvalue indicated a partial change in the attitude in the first and third row of Table.

The research showed a relatively low level of moral attitude of bank salesclerks in the banking sector of Slovakia. It can be assumed that low level of bank employee loyalty is transferred to the low acceptance rate of customer needs. Bank employees are not motivated to form long-term relationships with customers through high level of 
acceptance of their financial needs due the high turnover rate. Development of total customer satisfaction, partial satisfaction factors and feeling within a communication with bank is presented in Tab. 5, 6, 7 and 8 .

Table 5: Development of Total Customer Satisfaction in Slovakia from 2008 to 2012

\begin{tabular}{|l|r|r|r|}
\hline $\begin{array}{l}\text { Are you satisfied with the services and products } \\
\text { provided by the bank? }\end{array}$ & $\begin{array}{r}2012 \\
\text { in } \%\end{array}$ & $\begin{array}{r}2008 \\
\text { in } \%\end{array}$ & $\begin{array}{r}\text { p-value } \\
\text { (statistics) }\end{array}$ \\
\hline 1. Yes & 61 & 64 & $\begin{array}{r}0.46800 \\
(0.52800)\end{array}$ \\
\hline 2. No & 23 & 21 & $\begin{array}{r}0.55000 \\
(0.35800)\end{array}$ \\
\hline 3. I do not know & 16 & 15 & $\begin{array}{r}0.86000 \\
(0.03000)\end{array}$ \\
\hline \multicolumn{2}{|c|}{$\chi^{2}=0.69300, \mathrm{df}=2$} & \multicolumn{3}{|c|}{$\mathrm{p}$-value $=0.72930$} \\
\hline
\end{tabular}

Source: Own source

The overall customer satisfaction in Slovakia declined slightly.

Table 6: Reasons of Customer Satisfaction in 2008 and in 2012

\begin{tabular}{|l|r|r|r|}
\hline $\begin{array}{l}\text { What were you most satisfied with in the bank? (you } \\
\text { can specify up to three reasons) }\end{array}$ & $\begin{array}{r}2012 \\
\text { in \% }\end{array}$ & \multicolumn{1}{c|}{$\begin{array}{c}2008 \\
\text { in \% }\end{array}$} & \multicolumn{1}{|c|}{$\begin{array}{c}\text { Index of } \\
\text { change }\end{array}$} \\
\hline 1. Quick service in the branch & 28 & 22 & 0.273 \\
\hline 2. Possibility to use electronic banking & 67 & 49 & 0.367 \\
\hline 3. Quality of products and services & 22 & 17 & 0.294 \\
\hline 4. Comfortable and friendly services in the branch & 20 & 25 & -0.200 \\
\hline 5. Availability of subsidiary & 53 & 45 & 0.178 \\
\hline 6. Developed network of ATMs & 28 & 54 & -0.481 \\
\hline 7. Other (quality consulting services without fees) & 0 & 21 & -1.000 \\
\hline
\end{tabular}

Source: Own Source

Table 7: Feeling While Communicating with a Bank

\begin{tabular}{|l|r|r|r|}
\hline $\begin{array}{l}\text { Do you have a feeling that your bank is interested } \\
\text { in solving your financial issues, or the bank would } \\
\text { only like to sell something? }\end{array}$ & $\begin{array}{r}2012 \\
\text { in \% }\end{array}$ & $\begin{array}{r}2008 \\
\text { in \% }\end{array}$ & $\begin{array}{r}\text { p-value } \\
\text { (statistics) }\end{array}$ \\
\hline 1. Bank is very interested & 13 & 4 & $\begin{array}{r}<0,01 \\
(14.89700)\end{array}$ \\
\hline 2. Bank is sometimes interested & 31 & 30 & $\begin{array}{r}0.84000 \\
(0.04100)\end{array}$ \\
\hline 3. Bank is absolutely not interested & 11 & 16 & $\begin{array}{r}0.07800 \\
(3.11600)\end{array}$ \\
\hline $\begin{array}{l}\text { 4. Bank wants only sell something and make } \\
\text { money }\end{array}$ & 31 & 33 & $\begin{array}{r}0.66500 \\
(0.18700)\end{array}$ \\
\hline 5. I cannot judge & 14 & 17 & $\begin{array}{r}0.35000 \\
(0.87500)\end{array}$ \\
\hline \multicolumn{1}{|c|}{$\chi 2=18.85550, \mathrm{df}=4$} & \multicolumn{3}{|c|}{ p-value: $<0.01$} \\
\hline
\end{tabular}

Source: Own Source 
As shown in Tab. 6, reasons of customer satisfactions did not change. Clients more likely prefer cashless payment system because ATMs as the reason of customer satisfaction lost its importance and reversely, the importance of electronic banking increased significantly.

In 2012, clients significantly felt increased interest from banks to solve their financial issues, as evidenced by Tab 7. Despite this fact, only $13 \%$ of respondents said that bank is very interested in them. Almost one third of clients still believe that their bank is just trying to sell something and make money.

Table 8: Feelings of Customers of Bank while on Appointment in the Bank

\begin{tabular}{|l|r|r|r|}
\hline How do you feel when you visit the bank? & $\begin{array}{r}2012 \\
\text { in } \%\end{array}$ & $\begin{array}{r}2008 \\
\text { in } \%\end{array}$ & $\begin{array}{r}\text { p-value } \\
\text { (statistics) }\end{array}$ \\
\hline 1. They would like to help and advise me & 20 & 17 & $\begin{array}{r}0.35300 \\
(0.86100)\end{array}$ \\
\hline 2. It leaves good and serious impression & 53 & 58 & $\begin{array}{r}0.21900 \\
(1.51000)\end{array}$ \\
\hline 3. They could behave in a more decent way & 9 & 8 & $\begin{array}{r}0.76100 \\
(0.09000)\end{array}$ \\
\hline 4. I do not feel that it is very comfortable there & 13 & 13 & $\begin{array}{r}1.00000 \\
(0.00000)\end{array}$ \\
\hline 5. I have another feeling & 5 & 4 & $\begin{array}{r}0.69800 \\
(0.15000)\end{array}$ \\
\hline$\chi 2=2.1399, \mathrm{df}=4$ & \multicolumn{2}{|c|}{ p-value $=0.6995$} \\
\hline
\end{tabular}

Source: Own Source

Research brings only a slight change in feelings of banking clients. Number of clients who have a feeling that bank employees would really like to help them during the communication increased slightly. However, only one fifth of respondents reported this feeling.

Index of salesclerk satisfaction, Index of the acceptance of customer needs, Index of customer satisfaction and Index of customer satisfaction with bank employees are shown in Tab. 9. These indexes appropriately investigate and show trends of examined variables over the period.

Table 9: The Development of the Underlying Indexes

\begin{tabular}{|l|c|c|c|}
\hline \multicolumn{1}{|c|}{ Indicator } & 2012 & 2008 & $\begin{array}{c}\text { Index of } \\
\text { change }\end{array}$ \\
\hline Index of salesclerk satisfaction (Iss) & 0.39 & 0.50 & -0.220 \\
\hline Index of the acceptance of customer needs (Ian) & 0.33 & 0.49 & -0.327 \\
\hline Index of customer satisfaction (Ics) & 0.610 & 0.640 & -0.047 \\
\hline $\begin{array}{l}\text { Index of customer satisfaction with employees of } \\
\text { the bank (Ice) }\end{array}$ & 0.203 & 0.170 & 0.194 \\
\hline
\end{tabular}

Source: Own Source

Decline in Index of salesclerk satisfaction was accompanied by a decline in Index of the acceptance of customer needs and by a decline in Index of customer satisfaction in the 
banking sector of Slovakia. Index of customer satisfaction with bank employees increased despite achieving low value.

\section{Discussion}

In the context of financial crisis, discussion about moral aspects in banking business becomes more intense. The bank is often considered to be an immoral area (Icke, Caliskan, Ayturk and Icke, 2011, p. 291) which is primarily focused on risk and revenues. Paulet (2010, p. 298) argues that the banking sector is not in ethically free zone. According to the author, the financial crisis has shown that aggressive capitalism has demonstrated its limits, and it is necessary to add transparency and moral aspects to regulation in the banking system. Development of sustainable strategy means to redefine capitalism through criteria of efficiency which is focused not only on financial performance but also on economic and social conditions that guarantee a better wealth distribution for people.

In the historical context, it should be reminded that the largest Slovak bank went through the privatization process. The privatization of the largest Slovak bank has produced positive effects on the banking stability and performance, expansion of wide range of banking products to clients and strong focus on retail clients.

However, impacts of privatization processes on the social system and ethical approaches to applications in the banking are assessed with embarrassing feelings. Our researches and other findings, too, tend towards the conclusion that system care for employees deteriorated significantly due intense pressure to product sales, cancellation a number of social benefits and reduction of reassurances in relation to job retention in the terms of privatized banks. This trend was clearly confirmed by bank employees in the survey, who had the opportunity to work in the bank with state property and later with private ownership. A resolute decrease of employees in terms of the relatively high unemployment in Slovak banks was the side effect of privatization.

Besides social benefits reduction, negative assessment of leadership style is dominated in the banking sector.

The low quality of human resources management in privatized banks can be illustrated by a few cases: unofficial information leaked from one bank that management decided to fire all front-office staff with over 40 years of age and was not interested in other long-term and high-quality employees. Within two years in one branch of this bank, all employees were replaced by a method that is still viewed bitterly and with anger. To a great extent, management of another privatized bank preferred employees who spoke the language of bank's shareholders (but not English, which is the norm in the bank). Social impacts of privatization on employees were intense and the way the new managers coped with it could not have been assessed favorably. Ironically, many "professionals" and the media in Slovak Republic regarded this process with great enthusiasm.

Research results indicate that it can be assumed that morality (in relation to clients) may be higher in state banks than in private banks, which is in accordance with several authors (Icke, Caliskan, Ayturk and Icke 2011; Chatterjee and Lefcovitch 2009). Efforts of many politicians to solve the debt crisis in the euro zone by a massive privatization of firms (including banks) in concerned countries sounds pretty much paradoxically. 
Sigurthorsson (2012) claims that after banks in Iceland had been privatized, a massive increase of banks followed and led to the banking crisis. In other countries, such as Great Britain, banks were first privatized and later, in the time of the crisis, nationalized. It seems that each privatization wave is the "solution" of some problems and a source of many other problems.

Our research confirmed that managers of private banks create intense pressure on frontoffice employees which is translated into incorrect approach to clients. The employee of one important commercial bank who takes care of retail clients has expressed it eloquently: "We are forced to sell products regardless of client's needs through hard sales plan." According to this employee, the failure to fulfill sales plan again can usually lead to involuntary withdrawal from the bank. This managerial approach was also confirmed by employees of other banks. One of them provided an example, where her colleague persuaded the client to use the overdraft limit on current account (a special form of loan in Slovak Republic) to invest in mutual funds of the bank, which means a loss of about $5 \%$ per year. In our interviews, employees of banks mentioned other examples where they and their colleagues had not been interested in client's needs whatsoever, and tried to sell them unfavorable product in order to meet the sales plans.

Employees of banks are not loyal to their employers, and this attitude even seems not to be one of the priorities of bank management. According to Kocianová, it is expected from top managers to be able to lead employees to the knowledge implementation, to gain and retain a loyalty of employees and to manage and organize (2012, p. 67). The situation in the Slovak banking sector has the opposite characteristics, though. Staff often changes their jobs, are not satisfied and management principles and a methods of their superiors transferred to customers of the bank.

The crisis caused a fundamental change in public opinions on commercial banking and increased the pressure to apply ethical approaches in the banking significantly. Authors such as Paulet (2011), Graafland and Van de Ven (2011), Chatterjee and Lefcovitch (2009), Robin (2008) define barriers and criticize weaknesses of free competition in Anglo-Saxon capitalism and emphasize the importance of moral aspects in the context of regulation in banking sector (such as Tea, Paulišič and Krstinič-Nižič, 2011). SanJose, Retolaza and Gutierrez-Goiria (2011) argue that morality can represent a significant strategic advantage for the bank because banks with a high level of morality have not purchased toxic assets and therefore they have always avoided major financial difficulties during the crisis.

The crisis clearly demonstrated that the banking sector is not independent from the government in their business activities because of its regulation caused by social and political aspects. This regulation determines the existence of state guarantee systems like a banking business. On the same level of simplification, it can be said that commercial banks do business on their own account with foreign money which is guaranteed by the state. This subsequently creates a kind of private-public hybrid. In the final analysis, it is the citizens (taxpayers) who are responsible for management of bad (usually large) banks. Ideas, attitudes and opinions of certain economists about privately-owned commercial banks are not justified in this context, and they could be accepted only in one way, where banks would voluntarily leave the system of state guarantees and informed the general public about this. This would, however, 
significantly worsen their position to creditors and possibilities of achieving adequate performance respectively banks would establish their own robust and functional guarantee system. Negative experiences from activities of state banks in Slovak Republic or in other countries are not and cannot be the dominant criterion for evaluating ownership structures in commercial banking (the possibility of the existence and necessity of state banks is directly proportional to the political culture and morality which is governed in the country). Opinions on additional forms of government regulations (regulation of top managers' salaries, the possibility of additional taxation of banks etc.) have the same justification in this context. With regard to the negative impact of the global and financial crisis, it can be assumed that politicians under public pressure will put much more pressure on their enforcement.

\section{Conclusion}

Concepts of ethical behavior in business are not new, but they are now becoming particularly relevant because the crisis significantly highlighted the need of moral principles integration to the business.

Is business ethics a myth or reality? Our knowledge of business practices shows that the acceptance of moral principles of business is not integrated into management decisions of firms, and it cannot be expected that self-regulatory ethical business tools (such as CSR) will be effective.

Experiences with the application of ethical principles intended to acceptance of the opinion that from the perspective of bank management, social responsibility of banks and ethics are perceived as useful marketing tools for communicating with the public and are not integrated into policies of individual commercial banks. Experiences of the crisis demonstrated a lack of moral principles in the decision-making processes.

The approach of bank managers to their employees and approach of bank employees to acceptance of client's requirements which is determined by the overall level of satisfaction of bank's customers and partial satisfaction with personnel of the bank are the essential aspects of moral action of banks. These problems represent the subject of our research and were conducted in the banking environment of Slovakia in 2008 and in 2012.

Research results confirmed the scientific validation of the first assumption. The satisfaction of bank's employees and their loyalty declined due to higher labor intensity and low quality of personnel management in the banking sector. Index of salesclerks' satisfaction increased by $22 \%$ in the period under examination.

The scientific second presumption was confirmed. Attitudes of bank staff changed to the detriment of client during the crisis. Bank employees transformed the increase pressure on their productiveness into the form of unfair sales. Number of salesclerks who focused on selling at top prices and who accepted purchase of inappropriate products by the clients increased. Index of the acceptance of customer needs declined by $33 \%$ from 2008 to 2012.

Validity of third presumption was verified in this research. The overall level of customer satisfaction in Slovakia, which was measured by the Index of customer satisfaction, decreased by $4.7 \%$. Availability of banking products and services through 
electronic banking was the most important reason for customer satisfaction. Feelings of bank's customers while communicating with the bank and during a visit of branch bank did not change. Clients similarly thought that banks just wanted to sell something to them, and moreover, they felt that bank environment has a serious impression.

One part of the empirical research focused on an exclusive area of bank management which is difficult to encompass from academic point of view. Despite the limited sample of respondents, the research produced interesting impulses for improving personal work and appropriate approaches formation of client's needs acceptance in the commercial banking sector which could lead to increase the financial performance of the bank.

Trends in customer satisfaction development confirm their special sensitivity to acceptance of own financial needs for business contacts with the commercial bank. Therefore, it is necessary to form customer satisfaction by appropriate approach through high level of the acceptance of customer needs by employees of a bank because this fact causes positive effects on financial performance of the commercial banks.

Using effective implementation of business ethics in the commercial banking, it would be necessary to search and find new economic reasons for socially responsible behavior of banks. In order to be efficient in application of these activities in the banking sector, they have to primarily support strategic and business goals of the bank. In this context, taking care of own employees and customers is considered to be a very important part of business ethics activities in the commercial banking sphere.

\section{References}

BABAKUS, E., YAVAS, U., KARATEPE, O. M., AVCI, T. (2003). The Effect of Management Commitment to Service Quality on Employees'Affective and Performance Outcomes. Journal of the Academy of Marketing Science, pp.272-286. DOI: 10.1177/0092070303031003005

BASEL COMMITTEE ON BANKING SUPERVISION. (2009). International framework for liquidity risk measurement, standards and monitoring. Basel: Bank for International Settlements.

BASEL COMMITTEE ON BANKING SUPERVISION. (2010). A global regulatory framework for more resilience banks and banking system. Basel: Bank for International Settlements.

BAUMANN, CH., ELLIOTT, G., BURTON, S. (2012). Modeling customer satisfaction and loyalty: survey data versus data mining. Journal of Services Marketing, Vol. 26, Iss: 3, pp. 148-157. DOI: 10.1108/08876041211223951

BELÁS, J. (2010). Management komerčných bánk, bankových obchodov a operácii. Žilina: Georg.

BERRY, J. (2005). Franchising in Retail Financial Services. London: VRL Publishing Ltd. 
BHUTTO, N. A., LAGHARI, M. K., BUTT, F. D. (2012). A Comparative Study of Organizational Climate and Job Safisfaction in Public, Private and Foreign Banks. Asian Social Science, Vol. 8, No. 4, pp. 259-267. DOI: 10.5539/ass.v8n4p259

BLUNDELL-WIGNALL, A., ATKINSON, P. (2010). Thinking beyond Basel III: Necessary solutions for capital and liquidity. OECD Journal: Financial Market Trends. Issue 1, OECD.

COELHO, F., AUGUSTO, M.. (2010). Job Characteristics and the Creativity of Frontline Service Employees. Journal of Service Research. No. 13 (4), pp. 426-438. DOI: $10.1177 / 1094670510369379$

CROXFORD, H., ABRAMSON, F., JABLONOWSKI, A. (2006). The art of better retail banking. England, Chichester: John Wiley \& Sohs, Ltd.

DELOITTE, 2012: Prieskum: Viac ako polovica Slovákov nie je verná jednej banke. Bratislava, Tlačová správa, 21.6.2012. Retrieved from http://www.deloitte.com/view/sk_SK/sk/press/sk-press-releases/0b5e168d47 e08310VgnVCM2000001b56f00aRCRD.htm

ERNST \& YOUNG, 2012: Nová éra bankovnictví. Čěstí klienti chtějí, aby banky vyšly vice vstříc jejich potřebám. Praha, Tlačová správa, 25.6.2012. Retrieved from http://www.ey.com/CZ/cs/Newsroom/News-releases/2012_Nova-era-bankovnictvi

EUROPEAN CENTRAL BANK. (2001). The Monetary policy of the ECB. Frankfurt am Main: ECB.

FASSIN, Y., GOSSELIN, D. (2011). The Collapse of a European Bank in the Financial Crisis: An Analysis from Stakeholder and Ethical Perspectives. Journal of Business Ethics. Springer. No. 102, pp. 169-191. DOI: 10.1007/s10551-011-0812-2

GELADE, G., A., YOUNG, S. (2005). Test of a service profit chain model in the retail banking sector. Journal of Occupational and Organizational Psychology. Vol. 78, 2005, pp. 1-22.

GIBBONS, D. (2011). Held to account: a review of Corporate Social Responsibility in retail banking from the consumer perspective. London, Centre for Responsible Credit. Retrieved from http://www.responsiblecredit.org.uk/uimages/File/Held\%20to $\% 20$ Account $\% 20$ final\%20February\%202011.pdf

GRAAFLAND, J., J., VAN DE VEN, B. W. (2011). The Credit Crisis and the Moral Responsibility of Professionals in Finance. Journal of Business Ethics. Springer. No. 103, pp. 605-619.

HÄRLE, P., HEUSER, M., PFETSCH, S., POPPENSIEKER, T. (2010). Basel III. What the draft proposals might mean for European banking. Banking \& Securities. McKinsey \& Company. Mnichov.

HESKETT, J. L., JONES, T. O., LOVERMAN, G. W., SASSER, W. E., SCHLESINGER, L. A. (1994). Putting the Service-Profit Chain to Work. Harvard Business Review.

HOFREITER, R. (2011). Nová ekonomická sociológia a štruktúrny kontext trhu. Sociológia, Vol. 43, No.5, pp. 528-549. 
CHAKRABARTY, A. (2006). Barking up the wrong tree-factors influencing customer saficfaction in retail banking in the UK. International Journal of Applied Marketing, Vol. 1, No. 1.

CHATTERJEE, CH., LEFCOVITCH, A. (2009). Corporate social responsibility and banks. Amicus Curiae, Issue 78. Retrieved from http://sasspace.sas.ac.uk/2304/1/ Amicus78_ChatterjeeLefcovitch.pdf

ICKE, B., T., CALISCAN, E. N., AYTURK, Y., ICKE, M. A. (2011). An Empirical Research of Ethical Banking in Turkey. Journal of Modern Accounting and Auditing, Vol. 7. No. 3, pp. 289-304.

KAMAKURA, W. A., MITTAL, V., De ROSA, F., MAZZON, J. A. (2002). Assessing the Service-Profit Chain. Marketing science, Vol. 21, No. 3, pp. 294-317.

KOCIANOVÁ, R. (2012). Personální ř́zení. Východiska a vývoj. Praha: Grada Publishing.

KORAUŠ, A. (2011). Finančný marketing. Bratislava: Sprint.

LAGES, C. R., PIERCY, N. F. (2012) Key Drivers of Frontline Employee Generation of Ideas for Customer Service Improvement. Journal of Service Research. Vol. 15, No. 2, pp. 215-230. DOI: 10.1177/1094670511436005

LISÝ, J. a kol. (2007). Ekonómia v novej ekonomike. Bratislava: Iura Edition.

MADDERN, H., MAULL, R., SMART, A. (2007). Customer satisfaction and service quality in UK financial services. International Journal of Operations\&Production Management. Vol. 27, Iss: 9, pp. 999-1019. DOI: 10.1108/01443570710775838

MATZLER, K., RENZL, B. (2006). The Relationship between Interpersonal Trust, Employee Saficfaction, and Employee Loyalty. Total Quality Management, Vol. 17, No. 10, pp. 1261-1271.

MEJSTŘÍK, M., PEČENÁ, M., TEPLÝ, P. (2008). Základní principy bankovnictví. Praha: Karolinum.

MELTON, H. L., HARTLINE, M. D. (2010). Customer and Frontline Employee Influence on New Service Development Performance. Journal of Service Research, Vol. 13, pp. 411-425. DOI: 10.1177/1094670510369378

NEMEC, J. (2012). Chamtivost zatím nezná meze. Ekonom, Praha, Economia a.s., ročník LVI, číslo 12.

PALOMINO P. R., MARTINEZ, R. (2011). Human resource management and ethical behaviour: Exploring in the spanish banking industry. Ramon Llull Journal of Applied Ethics. Vol. 1, Issue 2.

PAULET, E. (2011) Banking ethics. Corporate Governance, Vol. 11, Issue 3, pp. 293 300. DOI: $10.1108 / 14720701111138715$

POLOUČEK, S. a kol. (2006). Bankovnictví. Praha: C.H.Beck. 
RENDTORFF, J., D., MATTSSON, J. (2012). Ethics in the bank internet encounter: an explorative study. Journal of Information, Communication and Ethics in Society, Vol. 10, Issue 1, pp. 36-51.

ROBIN, D. (2008). Toward an Applied Meaning for Ethics in Business. Journal of Business Ethics. Springer. No. 89, pp. 139-150.

ROSE, P.S. (2002). Commercial bank management. New York: The McGraw - Hill Companies.

SAARI, L. M., JUDGE, T. A. (2004). Employee attitudes and job satisfaction. Human Resource Management. Vol. 43, No. 4, 2004, pp. 395-407.

SAN-JOSE, L., RETOLAZA, J. L., GUTIERREZ-GOIRIA, J. (2011). Are Ethical Banks Different? A comparative analysis using Radical Afffinity Index. Journal of Business Ethics, No. 11, Issue 100, pp. 151-173.

SAURA, I. G., CONTRÍ, G. B., TAUlET, A.C., VElAZQUEZ, B. M. (2005). Relationships among customer orientation, service orientation and job satisfaction in financial services. Journal of Service Management, Vol. 16, No. 5, pp. 497-520.

SIGURTHORSSON, D. (2012). The Icelandic Banking Crisis: A Reason to Rethink CSR? Journal of Business Ethics. DOI: 10.1007/s10551-012-1207-8

SLOVENSKÁ BANKOVÁ ASOCIÁCIA. (2007). Etický kódex bánk v oblasti ochrany spotrebitel'a. Bratislava. Retrieved from http://www.vub.sk/files/sekundarnanavigacia/o-banke/hodnoty-principy/compliance/eticke-

kodexy/ombudsman_eticky_kodex.pdf

TEA, G., PAULIŠIČ M., KRSTINIČ-NIŽIČ, M. (2011). Bank Commitment to Etics. Information Management and Business Review, Vol. 3, No. 5, pp. 250-250.

YEE, R. W. Y., YEUNG, A. C., CHENG, T. C. E. (2010). An empirical study of employee loyalty, service quality and firm performance in the service industry. Int. J. Production Economics 124, pp. 109-120. DOI:10.1016/j.ijpe.2009.10.015

Van NIMWEGEN, T., SOETERS, J., Van LUIJK, H. (2004). Managing Values and Ethics in an International Bank. International Journal of Cross Cultural Management, Vol. 4, No. 1, pp. 101-122.

WALKER, A. G., SMITHER, J. W., WALDMAN, D. A. (2008). A Longitudinal examination of concomitant changes in team leadership and customer safisfaction. Personnel psychology, Vol. 61, pp 547-577.

WATKINS, J., P. (2011). Banking Ethics and the Goldman Rule. Journal of Economic Issues, Vol. XLV, No. 2. DOI: 10.2753/JEI0021-3624450213 